\title{
PENERAPAN MODEL PEMBELAJARAN DISCOVERY LEARNING BERBANTUAN LEMBAR KERJA SISWA (LKS) UNTUK MENINGKATKAN KEMAMPUAN ANALISIS DAN PRESTASI BELAJAR SISWA PADA MATERI KONSEP MOL KELAS X SMA NEGERI 1 BOYOLALI TAHUN AJARAN 2017/2018
}

\author{
Reti Prabaraita Nurisah, Widiastuti Agustina E.S. ${ }^{\star}$, dan Nurma Y. Indriyanti \\ Program Studi Pendidikan Kimia, FKIP, Universitas Sebelas Maret, Surakarta, Indonesia \\ *Keperluan korespondensi, telp : 081280660500, email: widiastuti_aes@staff.uns.ac.id
}

\begin{abstract}
ABSTRAK
Penelitian ini bertujuan untuk meningkatkan kemampuan analisis dan prestasi belajar siswa pada materi konsep mol kelas X SMA Negeri 1 Boyolali Tahun Ajaran 2017/2018 dengan penerapan model pembelajaran Discovery Learning berbantuan Lembar Kerja Siswa (LKS). Penelitian yang dilakukan merupakan Penelitian Tindakan Kelas (PTK) yang terdiri dari 2 siklus. Satu siklus terbagi 4 tahap antara lain: perencanaan, pelaksanaan, observasi, dan refleksi. Pada penelitian ini yang bertindak sebagai subjek adalah siswa kelas X MIPA 1 SMA Negeri 1 Boyolali Tahun Ajaran 2017/2018. Teknik analisis yang digunakan ialah deskriptif kualitatif. Pengumpulan data dilaksanakan dengan teknik observasi, wawancara, angket, serta tes. Data bersumber dari guru dan siswa. Penelitian ini menunjukkan hasil penerapan model pembelajaran Discovery Learning berbantuan LKS pada materi konsep mol dapat meningkatkan kemampuan analisis dan prestasi belajar siswa serta telah mencapai target baik aspek pengetahuan, sikap, dan keterampilan. Persentase ketercapaian kemampuan analisis siswa yang dihasilkan sebesar $75 \%$ pada siklus II. Persentase ketercapaian prestasi belajar aspek pengetahuan siklus II sebesar $75 \%$. Persentase ketercapaian aspek sikap pada siklus I yaitu $100 \%$, sedangkan besarnya persentase ketercapaian aspek keterampilan siklus I yaitu 100\%.
\end{abstract}

Kata Kunci : Penelitian Tindakan Kelas, Discovery Learning, Kemampuan Analisis, Prestasi Belajar, Konsep Mol

\section{PENDAHULUAN}

Kualitas pendidikan suatu bangsa menentukan kualitas sumber daya manusianya. Permasalahan pendidikan Indonesia adalah masih rendahnya mutu pendidikan yang dibuktikan dengan hasil survey PISA (Programme for International Student Assessment), capaian pendidikan Indonesia pada aspek sains yaitu 403 masih di bawah rata-rata OECD (Organisation for Economic Cooperation and Development) yaitu 493, sedangkan capaian aspek membaca adalah 397 masih dibawah ratarata OECD yaitu 493 dan capaian aspek matematika ialah 386 masih dibawah rata-rata OECD yaitu 490 dari 72 negara yang mengikuti tes PISA [1]. Hal tersebut dapat disebabkan oleh kesalahan dalam pemilihan metode dan media yang digunakan. Pemilihan metode dan media pembelajaran harus disesuaikan dengan tujuan pembelajaran, kondisi siswa dan lingkungannya, serta karakteristik materi yang akan disampaikan. Penggunaan metode dan media pembelajaran yang sesuai diharapkan dapat membuat siswa berpartisipasi aktif dalam proses belajar mengajar maka, prestasi belajar siswa meningkat sehingga, mutu pendidikan juga meningkat.

Pelaksanaan pembelajaran di SMA Negeri 1 Boyolali sudah menerapkan Kurikulum 2013 (K13) sejak tahun 2013. Namun kenyataannya, penerapan K13 dalam pembelajaran kimia masih belum optimal contohnya dalam implementasi model-model pembelajaran. Guru dalam menerapkan model tersebut 
belum melaksanakan setiap sintaks pada model tersebut atau masih setengahsetengah. Bahkan guru lebih sering menggunakan metode ceramah karena dianggap lebih praktis dan tidak banyak menyita waktu serta jarang menggunakan media pembelajaran karena kurangnya penguasaan teknologi. Hal itu membuat siswa cenderung menerima apa saja yang diberikan oleh guru tanpa memberikan pendapat atau bertanya. Metode pembelajaran tersebut mengakibatkan siswa tidak memiliki kesempatan untuk membangun sendiri pengetahuannya, sehingga pemahaman siswa akan materi yang disampaikan masih kurang. Akibatnya, siswa memiliki pemikiran bahwa kimia merupakan pelajaran yang sulit.

IImu kimia merupakan ilmu yang bersifat kontinyu atau saling berhubungan antara konsep satu dengan yang lainnya. Oleh karena itu, ilmu kimia harus dipelajari secara runtut dan berkesinambungan sehingga konsep yang diterima siswa dapat terasimilasi dan terakomodasi dengan benar. Contohnya pada materi stoikiometri yang akan digunakan terus menerus baik pada materi kelas XI maupun XII. Perhitungan stoikiometri merupakan salah satu materi kimia yang kurang menarik dan sangat sulit pada sekolah menengah atas [2]. Hal ini sesuai hasil wawancara dengan 15 siswa menunjukkan bahwa 10 dari 15 siswa menganggap stoikiometri adalah materi sulit. Siswa sering menghafalkan rumusrumus yang ada, akan tetapi tidak semua siswa bisa memiliki daya ingat yang dapat bertahan lama. Selain itu, dengan menghafal belum tentu siswa memiliki pemahaman yang baik, karena dalam menyelesaikan soal-soal stoikiometri dibutuhkan pemahaman dan kemampuan analisis yang baik.

Stoikiometri memiliki submateri antara lain persamaan kimia, hukumhukum dasar kimia, konsep mol, dan perhitungan kimia. Untuk dapat menguasai materi stoikiometri diperlukan penguasaan sub-sub materinya terutama konsep mol, karena konsep mol mendasari setiap perhitungan kimia. Hal ini sesuai dengan hasil penelitian yang menyatakan bahwa rendahnya prestasi belajar hukum dasar kimia dipengaruhi oleh penguasaan materi konsep mol [3].

Berdasarkan buku nilai kelas $X$ MIPA di SMA Negeri 1 Boyolali diperoleh daftar nilai rata-rata Penilaian Akhir Semester (PAS) Semester Ganjil TA. 2017/2018 yang dapat dilihat pada Tabel 1.

Tabel 1. Daftar nilai rata-rata Penilaian Akhir Semester (PAS) Semester Ganjil TA. 2017/2018

\begin{tabular}{ccc}
\hline Kelas & $\begin{array}{c}\text { Nilai Rata- } \\
\text { Rata PAS }\end{array}$ & $\begin{array}{c}\text { Ketuntasan } \\
\text { PAS }(\%)\end{array}$ \\
\hline X MIPA 1 & 61 & 61,11 \\
X MIPA 2 & 83 & 88,89 \\
X MIPA 3 & 62 & 63,89 \\
X MIPA 4 & 78 & 88,89 \\
X MIPA 5 & 82 & 94,44 \\
X MIPA 6 & 75 & 91,67 \\
X MIPA 7 & 75 & 88,89 \\
X MIPA 8 & 77 & 91,67 \\
\hline
\end{tabular}

Tabel 1. menunjukkan bahwa nilai rata-rata PAS kelas X MIPA 1 memiliki nilai paling rendah di antara kelas lainnya yaitu 61. Selain itu, kelas tersebut memiliki persentase ketuntasan paling rendah yaitu $61,11 \%$. Oleh karena itu, diperlukan upaya perbaikan pada siswa kelas X MIPA 1 SMA Negeri 1 Boyolali agar mengalami peningkatan prestasi belajar.

Hasil wawancara dengan guru kimia menyebutkan bahwa kemampuan analisis siswa masih rendah yang menyebabkan rendahnya nilai rata-rata kelas dan ketidaktuntasan pada materi konsep mol. Siswa dirasa belum mampu menguraikan keseluruhan pertanyaan dan merasa bingung dalam memecahkan masalah tentang konsep mol. Selain itu, siswa juga kurang mampu menganalisis soal tentang perhitungan kimia. Karakteristik materi konsep mol yaitu banyak menggunakan rumus, sehingga dalam menyelesaikan masalah melibatkan lebih dari satu rumus, maka dibutuhkan kemampuan analisis yang baik [4]. Melalui kemampuan analisis, peserta didik dapat mengintepretasi informasi/ide-ide, mengidentifikasi pernyataan dan informasi yang akan disajikan, dan menguraikan hubungan dari bagian-bagian suatu konsep untuk 
memberikan keputusan [5]. Hal tersebut didukung oleh hasil prasiklus yang menunjukkan bahwa persentase kemampuan analisis siswa kelas X MIPA 1 SMA Negeri 1 Boyolali sebesar 25\% kategori sangat tinggi, $11 \%$ kategori tinggi, 32\% kategori sedang dan 32\% kategori rendah.

Berdasarkan uraian permasalahan di atas, maka perlu dilakukan Penelitian Tindakan Kelas (PTK) atau Classroom Action Research (CAR) untuk memperbaiki dan meningkatkan kualitas proses pembelajaran sehingga prestasi belajar dan kemampuan analisis siswa menjadi lebih baik. PTK merupakan upaya peningkatan kualitas pembelajaran melalui tindakan perbaikan untuk memecahkan masalah [6].

Peningkatan kualitas belajar siswa SMA Negeri 1 Boyolali dapat dilakukan dengan penerapan model pembelajaran Discovery Learning yang sesuai dengan Permendikbud Nomor 65 Tahun 2013. Penggunaan model Discovery Learning dapat membuat siswa aktif dalam pembelajaran serta meningkatkan prestasi belajar dan kemampuan analisis siswa. Model pembelajaran Discovery Learning dimulai dengan guru memberikan rangsangan berupa pertanyaan atau permasalahan kepada siswa kemudian siswa melakukan penyelidikan untuk menemukan konsep dari permasalahan yang diberikan oleh guru secara mandiri. Guru berperan sebagai fasilitator dengan memberikan arahan atau petunjuk kepada siswa untuk menemukan konsep secara mandiri. Dengan demikian, siswa akan memiliki kesempatan untuk belajar secara mandiri, meningkatkan kemampuan analisis dan dapat menemukan solusi untuk memecahkan masalah.

Pembelajaran Discovery Learning dapat meningkatkan prestasi dan keterampilan proses sains siswa. Peningkatan tersebut terjadi karena pembelajaran Discovery Learning mendorong siswa untuk menemukan sendiri solusi atau pemecahan atas masalahnya sendiri sehingga, siswa tidak hanya berpartisipasi aktif dalam proses pembelajaran tetapi juga melatih keterampilan proses sains untuk memecahkan masalah tersebut [7].
Media pembelajaran yang sering digunakan SMA Negeri 1 Boyolali adalah handout, modul, dan Lembar Kerja Siswa (LKS). Penggunaan media LKS di SMA Negeri 1 Boyolali belum optimal, karena media tersebut hanya digunakan pada materi yang memiliki karakteristik banyak teori dan hafalan saja. LKS merupakan panduan untuk latihan pengembangan aspek kognitif maupun panduan untuk pengembangan aspek pembelajaran dalam bentuk panduan eksperimen atau demonstrasi [8]. Media LKS dapat diterapkan pada materi dengan karakteristik banyak terori dan hafalan maupun banyak rumus dan hitungan untuk menemukan suatu konsep atau teori.

Media LKS sangat cocok diaplikasikan ke dalam materi konsep mol, dimana siswa dapat belajar secara mandiri dengan soal latihan yang terstruktur dan terarah [9]. Penggunaan LKS yang optimal pada materi konsep mol dengan model Discovery Learning dapat meningkatkan kemampuan analisis dan prestasi belajar siswa.

Berdasarkan latar belakang di atas, penelitian tindakan kelas ini penting dilakukan untuk meningkatkan kualitas pendidikan di SMA Negeri 1 Boyolali. Model pembelajaran Discovery Learning dengan media LKS mampu meningkatkan kemampuan analisis dan prestasi belajar pada materi konsep mol.

\section{METODE PENELITIAN}

Penelitian dilaksanakan SMA Negeri 1 Boyolali. Jenis penelitian yang dilakukan merupakan Penelitian Tindakan Kelas (PTK) dimana didalamnya terdapat 2 siklus. Secara umum, satu siklus memiliki empat tahap yaitu perencanaan, pelaksanaan, observasi, dan refleksi [10-11]. Subyek pada penelitian ini adalah siswa kelas X MIPA 1 SMA Negeri 1 Boyolali Tahun Ajaran 2017/2018. Guru dan siswa merupakan sumber data pada penelitian ini. Teknik pengumpulan data melalui tes serta non tes yang terdiri dari observasi, wawancara, angket, dan tes.

Analisis data pada pelaksanaan Penelitian Tindakan Kelas dilakukan dari awal hingga didapatkannya data terakhir. 
Hasil data yang diperoleh dari penelitian kemudian dianalisis dan diolah secara deskriptif kualitatif. Model analisis Miles dan Huberman merupakan teknik analisis kualitatif yang digunakan pada penelitian ini, yaitu proses reduksi data, penyajian data, penarikan kesimpulan serta verifikasi. Validitas data pada penelitian ini diperiksa dengan teknik triangulasi. Triangulasi merupakan suatu teknik untuk memeriksa keabsahan data dengan menggunakan faktor lain yang berada di luar data itu yang berperan sebagai pembanding data tersebut [12].

\section{HASIL DAN PEMBAHASAN}

Penelitian ini merupakan penelitian tindakan kelas dengan menerapkan model pembelajaran Discovery Learning dengan media LKS pada materi konsep mol. Pembelajaran ini merupakan pembelajaran yang berpusat pada siswa dimana siswa dituntun menemukan konsep pengetahuannya sendiri dan guru bertindak sebagai fasilitator. Penerapan model pembelajaran Discovery Learning membantu siswa untuk memahami konsep teoritis materi konsep mol melalui kegiatan penemuan dengan LKS yang diberikan guru kepada siswa. Selain itu, model Discovery Learning diharapkan juga membantu siswa dalam meningkatkan kemampuan analisis siswa dalam menelaah soal-soal pada materi konsep mol dan dapat mengembangkan konsep-konsep yang dimiliki sehingga mampu meningkatkan pemahaman siswa tentang materi konsep mol.

\section{Siklus I}

\section{a. Perencanaan Tindakan}

Silabus yang digunakan merupakan silabus kurikulum 2013 yang telah disusun berdasarkan Permendikbud No. 22 Tahun 2016. Silabus tersebut dimodifikasi sesuai dengan kondisi dan kebutuhan sekolah agar sesuai dengan model pembelajaran yang akan diterapkan dalam penelitian tindakan kelas dan disetujui oleh guru yang bersangkutan. Berdasarkan silabus tersebut, peneliti menyusun instrumen-instrumen pembelajaran yang diperlukan. Instrumen pembelajaran yang pertama yaitu
Rencana Pelaksanaan Pembelajaran (RPP). Dalam silabus alokasi waktu yang disediakan untuk materi larutan penyangga adalah 5 jam pelajaran (JP). Berdasarkan waktu tersebut, peneliti membuat rencana pembelajaran untuk siklus I dengan rincian $3 \mathrm{JP}$ untuk penyampaian materi konsep mol dan 2 JP untuk evaluasi kegiatan pembelajaran siklus I. Penyusunan instrumen selanjutnya adalah alat evaluasi pembelajaran yang mencakup aspek pengetahuan, sikap, keterampilan, kemampuan analisis dan LKS.

\section{b. Pelaksanaan Tindakan}

Sub pokok bahasan yang dipelajari pada siklus I diantaranya menghitung jumlah partikel suatu zat, menghitung massa atom relatif dan massa molekul relatif suatu zat, menghitung massa molar suatu zat, menghitung volume molar suatu gas, menerapkan Hipotesis Avogadro dan Hukum Gas Ideal dalam perhitungan kimia, interkonversi mol, menghitung molaritas suatu larutan.

Kegiatan pembelajaran diawali dengan memberi apersepsi yang masih berkaitan dengan kehidupan sehari-hari. Selanjutnya siswa menyimak tujuan pembelajaran, kemudian menyimak penjelasan singkat dari guru. Tahap selanjutnya, siswa diminta mencari informasi yang luas dan ketika menjawab soal diskusi dalam LKS menggunakan berbagai sumber, baik dari buku pegangan maupun internet yang dikerjakan bersama kelompok masing-masing yang telah dibagi oleh guru secara heterogen. Pada tahap ini, siswa diberikan kesempatan bertanya pada guru jika mengalami kesulitan dalam mengerjakan soal diskusi dalam LKS. Selain itu, siswa juga diberi kesempatan untuk mengidentifikasi dan menganalisis masalah yang diberikan.

Setelah proses diskusi selesai, siswa diberi kesempatan untuk menyajikan hasil diskusi kelompok di depan kelas dan kelompok lain diperbolehkan untuk memberi tanggapannya. Diskusi ditutup dengan guru menyamakan persepsi dan memberikan penguatan sehingga siswa menjadi lebih paham. 
Guru bersama-sama dengan siswa menyimpulkan hasil pembelajaran.

Siklus I diakhiri dengan dilakukannya tes pengetahuan agar dapat mengetahui tingkat pemahaman siswa terhadap materi konsep mol berupa 7 butir soal uraian yang merupakan tes aspek pengetahuan sekaligus aspek kemampuan analisis, serta angket penilaian sikap terdiri dari 40 butir soal.

\section{c. Observasi}

Observasi dilakukan oleh peneliti dibantu oleh 3 (tiga) observer untuk menilai aspek sikap dan aspek keterampilan siswa pada saat kegiatan belajar mengajar siklus I sedang berlangsung.

\section{d. Hasil Tindakan Siklus I}

Berdasarkan hasil analisis tes kemampuan analisis didapatkan persentase kategori rendah sebesar 100\%, aspek pengetahuan pada siklus I menunjukkan terdapat 2 siswa (7\%) sudah melampaui kriteria ketuntasan minimal (KKM) dan 26 siswa (93\%) belum melampaui KKM. Dari hasil tersebut dapat disimpulkan bahwa target aspek kemampuan analisis dan pengetahuan belum mencapai target yang ditentukan yaitu $60 \%$. Sedangkan, hasil penilaian aspek sikap pada siklus I, siswa yang mempunyai kategori sikap sangat baik sebanyak 32\% (9 siswa) dan kategori baik sebanyak 68\% (19 siswa). Untuk hasil penilaian aspek keterampilan adalah $86 \%$ atau 24 siswa berkategori sangat baik dan $14 \%$ atau 4 siswa berkategori baik. Berdasarkan target yang telah ditetapkan maka, aspek sikap dan keterampilan sudah mencapai target yaitu $70 \%$ minimal berkategori baik. Hasil persentase ketercapaian siklus I dapat dilihat pada Tabel 2.

Tabel 2. Ketercapaian Target pada Siklus I

\begin{tabular}{lccc}
\hline \multicolumn{1}{c}{ Aspek } & $\begin{array}{c}\text { Target } \\
(\%)\end{array}$ & $\begin{array}{c}\text { Hasil } \\
(\%)\end{array}$ & Kriteria \\
\hline Kemampuan & 60 & 0 & $\begin{array}{c}\text { Tidak } \\
\text { Tercapai } \\
\text { Analisis }\end{array}$ \\
Pengetahuan & 60 & 7 & $\begin{array}{c}\text { Tidak } \\
\text { Tercapai }\end{array}$ \\
Sikap & 70 & 100 & Tercapai \\
Keterampilan & 70 & 100 & Tercapai \\
\hline
\end{tabular}

\section{e. Refleksi}

Berdasarkan hasil penelitian yang diperoleh pada pembelajaran siklus I, terdapat aspek kemampuan analisis dan pengetahuan yang belum mencapai target yang ditentukan. Hal tersebut karena siswa belum terbiasa untuk menganalisis permasalahan, merumuskan masalah, dan menyelesaikan masalah serta menyusun laporan diskusi karena membutuhkan waktu yang banyak dan perlu kerjasama. Penggunaan model Discovery Learning juga belum optimal, masih banyak siswa yang belum aktif dalam kegiatan diskusi dengan menggunakan LKS dikarenakan siswa membutuhkan arahan dan bimbingan yang lebih dari guru agar mudah memahami inti dari kegiatan diskusi. Peranan model pembelajaran Discovery Learning dan media LKS pada siklus I belum tercapai karena belum mampu meningkatkan kemampuan analisis dan prestasi belajar siswa. Hal tersebut membuat kemampuan analisis dan pengetahuan siswa belum mencapai target. Maka dari itu dilaksanakan tindakan selanjutnya yaitu perlu direncanakan adanya pembelajaran siklus II. Untuk aspek sikap dan keterampilan tidak dilaksanakan penilaian pada siklus II karena sudah mencapai $100 \%$ dari target yang telah ditentukan.

\section{Siklus II}

\section{a. Perencanaan Tindakan}

Hasil refleksi pada siklus I menunjukkan perlunya dilakukan perbaikan terhadap hambatan-hambatan yang terjadi pada siklus I, sehingga dirancang rencana pembelajaran siklus II. Tindakan tersebut antara lain mendiskusikan indikator yang belum tuntas pada evaluasi siklus I. Diharapkan guru mampu meningkatkan kemampuan analisis dan prestasi belajar dengan membimbing siswa memecahkan permasalahan pada materi konsep mol. Dengan demikian, hasilnya mencapai target dan lebih baik pada siklus II.

\section{b. Pelaksanaan Tindakan}

Pelaksanaan saat siklus II, pembahasan materi difokuskan pada 3 
indikator antara lain menghitung massa molar suatu zat, menghitung volume molar suatu gas, dan interkonversi mol. Hal tersebut dilakukan dengan cara mendalami pemecahan masalah pada soal-soal yang terdapat pada LKS. Siswa diharapkan mampu mengevaluasi bagian mana yang dirasa masih sulit, hal ini dibuktikan dengan adanya beberapa siswa yang menanyakan langkah-langkah tertentu pada saat mengerjakan soal. Selain itu, siswa mampu mengidentifikasi masalah, menganalisis masalah dan memecahkan masalah dalam kegiatan diskusi

Siklus II diakhiri dengan dilakukannya tes pengetahuan untuk dapat mengetahui tingkat kepahaman siswa terhadap materi konsep mol berupa 3 butir soal uraian yang merupakan tes aspek pengetahuan sekaligus aspek kemampuan analisis.

\section{c. Observasi}

Tahap observasi dilakukan oleh peneliti dan beberapa observer untuk menilai aspek sikap siswa pada saat kegiatan belajar mengajar siklus II sedang berlangsung.

\section{d. Hasil Tindakan Siklus II}

Berdasarkan analisis hasil tes yang telah dilaksanakan pada pembelajaran siklus II, diperoleh ketercapaian penilaian kemampuan analisis pada siklus II mencapai $11 \%$ atau 3 siswa berkategori sangat tinggi, 64\% atau 18 siswa berkategori tinggi dan 7 siswa atau 25\% berkategori sedang. Sedangkan, aspek pengetahuan diperoleh sebanyak 21 siswa $(75 \%)$ sudah melampaui kriteria ketuntasan minimal (KKM) dan 7 siswa $(25 \%)$ belum melampaui KKM. Dari hasil tersebut, dapat disimpulkan bahwa aspek kemampuan analisis dan pengetahuan telah mencapai target pada siklus II yaitu sebesar $60 \%$.

Hasil persentase ketercapaian target siklus II pada aspek kemampuan analisis dan pengetahuan dapat dilihat pada Tabel 3.
Tabel 3. Ketercapaian Target pada Siklus II

\begin{tabular}{|c|c|c|c|}
\hline Aspek & $\begin{array}{c}\text { Target } \\
(\%)\end{array}$ & $\begin{array}{l}\text { Hasil } \\
(\%)\end{array}$ & Kriteria \\
\hline $\begin{array}{l}\text { Kemampuan } \\
\text { Analisis }\end{array}$ & 60 & 75 & Tercapai \\
\hline Pengetahuan & 60 & 75 & Tercapai \\
\hline
\end{tabular}

Berdasarkan hasil penelitian pada siklus II dapat dilihat bahwa kemampuan analisis dan pengetahuan sudah mencapai target yang telah ditentukan. Sehingga dapat disimpulkan bahwa pembelajaran pada materi konsep mol dengan menerapkan model pembelajaran Discovery Learning berbantuan LKS telah berhasil karena sudah mencapai target yang telah ditetapkan. Penelitian diakhiri pada siklus II karena kualitas proses yaitu kemampuan analisis serta prestasi belajar siswa yang mencakup aspek pengetahuan, sikap serta keterampilan sudah mencapai target yang telah ditentukan.

Hasil penelitian ini sesuai dengan penelitian sebelumnya yang menunjukkan bahwa model pembelajaran Discovery Learning efektif meningkatkan keterampilan berpikir kritis serta meningkatkan sikap positif terhadap materi stoikiometri [13]. Selain itu, penelitian lainnya menyimpulkan bahwa penggunaan media LKS pada materi konsep mol dapat meningkatkan prestasi belajar dan kemampuan analisis siswa kelas X [14].

\section{Perbandingan Hasil Tindakan antarsiklus}

Setiap pelaksanaan siklus, dilakukan penilaian terhadap aspek pengetahuan dan kemampuan analisis di akhir siklus, observasi aspek sikap dilakukan pada proses pembelajaran berlangsung dan angket penilaian diri pada akhir siklus, dan aspek keterampilan pada proses pembelajaran berlangsung.

Berdasarkan penelitian yang telah dilakukan, tes kemampuan analisis siklus I siswa dengan kategori rendah sebanyak 28 siswa (100\%). Hasil tes kemampuan analisis siklus II menunjukkan bahwa siswa dengan kategori kemampuan analisis sangat tinggi sebanyak 3 siswa (11\%), kategori tinggi sebanyak 18 siswa 
(64\%) dan 7 siswa atau 25\% berkategori sedang. Aspek pengetahuan pada siklus I menunjukkan terdapat 2 siswa (7\%) telah tuntas dan 26 siswa (93\%) belum tuntas. Aspek pengetahuan pada siklus II diperoleh sebanyak 21 siswa (75\%) telah tuntas dan 7 siswa (25\%) belum tuntas. Perbandingan hasil aspek pengetahuan siswa pada siklus I dan siklus II dapat dilihat pada Gambar 1.

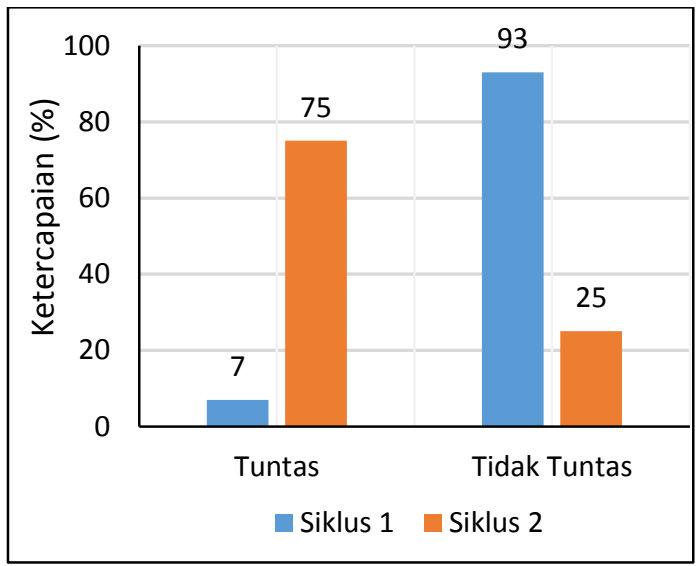

Gambar 1. Perbandingan Ketercapaian Ketuntasan Aspek Pengetahuan Siswa antara Siklus I dan Siklus II

Penilaian pada aspek sikap dan keterampilan dilakukan dengan observasi pada proses pembelajaran berlangsung. Hasil penilaian aspek sikap dan keterampilan pada siklus I diperoleh ketercapaian sebesar 100\% dengan kategori minimal baik, sehingga untuk aspek sikap dan keterampilan tidak diperbaiki kembali pada siklus II.

Peningkatan kemampuan analisis dan prestasi belajar pada penelitian ini didukung dengan penggunaan media berupa LKS. Peran yang dimiliki LKS cukup besar dalam penerapan model pembelajaran Discovery Learning yaitu sebagai media untuk mempermudah tercapainya tujuan pembelajaran, sebab LKS merupakan panduan belajar yang dapat menstimulasi siswa untuk mengasah kemampuan analisisnya melalui soal-soal diskusi dan soal latihan yang ada di dalam LKS tersebut.

\section{KESIMPULAN}

Berdasarkan hasil penelitian yang telah dilaksanakan, maka dapat disimpulkan bahwa penerapan model pembelajaran Discovery Learning berbantuan Lembar Kerja Siswa (LKS) dapat meningkatkan kemampuan analisis dan prestasi belajar siswa pada materi konsep mol kelas X SMA Negeri 1 Boyolali Tahun Ajaran 2017/2018 serta telah mencapai target yang telah ditentukan. Persentase capaian kemampuan analisis siswa meningkat dari $0 \%$ pada siklus I menjadi $75 \%$ pada siklus II dan telah mencapai target yaitu $60 \%$. Prestasi belajar aspek pengetahuan pada siklus I sebesar 7\% meningkat menjadi $75 \%$ pada siklus II dan telah mencapai target yaitu 60\%. Prestasi belajar aspek sikap pada siklus I sudah mencapai target sebesar $100 \%$ sehingga tidak dilanjutkan pada siklus II, sedangkan prestasi belajar aspek keterampilan pada siklus I sudah mencapai target pula yaitu $100 \%$ sehingga tidak dilanjutkan pada siklus II, dimana prestasi belajar aspek sikap dan keterampilan memiliki target capaian sebesar $70 \%$.

\section{UCAPAN TERIMA KASIH}

Peneliti mengucapkan terima kasih kepada Bapak Drs. Agung Wardoyo, selaku Kepala SMA Negeri 1 Boyolali yang telah memberikan izin penelitian, serta Ibu Dra. Dwi Yuliasih, M.Pd., selaku guru pengampu kimia yang telah mengijinkan peneliti melakukan penelitian di kelas X MIPA SMA Negeri 1 Boyolali.

\section{DAFTAR RUJUKAN}

[1] PISA, 2016, PISA 2015 Results in Focus, OECD, 16. Diperoleh pada 26 Desember 2017 dari https://doi.org/10.1787/978926426 6490-en.

[2] Schmidt, H.J. \& Jignéus, Cecilia, 2003, Chemistry Education: Research and Practice, 4(3), 305-317. 
[3] Kurniawati, Desi., Masykuri, M., \& Saputro, S., 2016, Jurnal Pendidikan Kimia, 5(1), 88-95.

[4] P, Yosia P. D., Mulyani, B. \& Utami, B., 2016, Jurnal Pendidikan Kimia, $5(1), 1-8$.

[5] Facione, P. A., 1990, The California Academic Press, 423(c), $1-19$.

[6] Kusumah, W \& Dwitagama, D., 2010, Mengenal Penelitian Tindakan Kelas Edisi Kedua, Jakarta: PT Indeks.

[7] Balım, Ali Günay., 2009, Egitim Arastirmalari-Eurasian Journal Educational Resaarch, (35), 1-20.

[8] Trianto, 2010, Mendesain Model Pembelajaran Inovatif-Progresif Konsep Landasan, dan Implementasinya pada Kurikulum Tingkat Satuan Pendidikan (KTSP), Jakarta: Kencana Prenada Media Group.
[9] Maratusholihah, N. F. \& Novita D. 2014, UNESA Journal of Chemical Education, 3(1), 48-53.

[10] Sutama, 2010, Metode Penelitian Pendidikan: Kuantitatif, Kualitatif, PTK, R\&D, Surakarta: Fairuz Media.

[11] Arikunto, S., 2011, Dasar-dasar Evaluasi Pendidikan, Jakarta: Bumi Aksara.

[12] Sugiyono, 2015, Metode Penelitian Pendidikan (Pendekatan Kuantitatif, Kualitatif, dan R\&D), Bandung: Alfabeta.

[13] Gupta, T., dkk., 2014, Journal of Chemical Education, 92(1), 32-38.

[14] Suryani, L. B., Saputro, A. N. C. \& Martini, K. S., 2015, Jurnal Pendidikan Kimia, 4(4), 186-192. 